\title{
Obrazowanie ziemi wielokrotnej. Szkic o wybranych sposobach przedstawiania nowych pograniczy niemiecko-polskich
}

\begin{abstract}
Streszczenie
Celem tej wypowiedzi jest zaproponowanie terminów pomocnych w analizie sposobów przedstawiania nowych pograniczy niemiecko-polskich, które powstały po drugiej wojnie światowej. Terminy te można wykorzystać w dydaktyce akademickiej. Pozwalają one bowiem skoncentrować uwagę na policentryzmie i problemach Innego. W artykule - obok badawczego pokazano (i dookreślono) następujące rodzaje prezentacji pograniczy: eliminacyjno-jednostronny (na przykładzie wierszy polskich z drugiej połowy lat czterdziestych XX wieku); odkrywczo-dokumentacyjny (na przykładzie artystycznego dokumentu filmowego powstałego w XXI wieku); prezentacyjno-archiwizujący (na przykładzie antologii narracji pograniczy sprzed 1945 roku). Istotę wypowiedzi stanowi rozwinięcie definicji pojęcia: ziemia wielokrotna. Ten metatermin ma charakter policentryczny. Jego użycie determinuje wieloperspektywiczny ogląd terytoriów różnych pograniczy. Może też być wykorzystywany w dydaktyce jako środek ułatwiający zrozumienie oraz opis zjawisk i procesów charakterystycznych dla pograniczy. Określenie „ziemia wielokrotna” umożliwia rezygnację ze słownictwa wywodzącego z mitów, na przykład polskiego „ziem odzyskanych” czy niemieckiego „utraconego Heimatu”. W artykule została również zwrócona uwaga na konieczność szczególnej wrażliwości metajęzykowej w badawczych i edukacyjnych opisach pograniczy.
\end{abstract}

1 Katarzyna Monika Taborska, Wydział Humanistyczny, Akademia im. Jakuba z Paradyża, Polska, e-mail: katarzynataborska@wp.pl, ORCID ID: htpps://orcid.org/0000-0002-0038-9488. 


\title{
Słowa kluczowe:
}

pogranicza niemiecko-polskie, ojczyzna wielokrotna, ziemia wielokrotna, literatura pogranicza, literatura miejsca

\begin{abstract}
The goal of the text is to put forth a number of terms that will facilitate the analysis of the ways in which new German-Polish borderlands are presented that focus on the issues of the Other. Alongside the exploratory perspective, the article identifies (and terms) the following ways: eliminative-one-sided (on the example of Polish poems from the late 1940s); revelatory-documenting (exemplified by an artistic film documentary made in the $21^{\text {st }}$ ); expository-archiving (based on three anthologies of borderland narratives prior to 1945). The essence of the article also includes an expansion of the definition of the term "multiple land". This meta-term is of polycentric nature. Its use determines a multi-perspective view of various borderland territories. It may be used in didactics as a means of facilitating the understanding and description of phenomena and processes characteristic of borderlands. The term multiple land enables a retreat from myth-based vocabulary, such as the Polish "regained territories" or German "Lost Heimat”. The article also emphasizes the need for a particular metalinguistic sensitivity in academic and educational descriptions of borderlands.
\end{abstract}

\section{Keywords:}

German-Polish borderlands, multiple homeland, multiple land, literature of the borderlands, literature of the place

Zajęcia z zakresu kultur pograniczy są jednym z tych przedmiotów akademickich, które wymagają szczególnych umiejętności pedagogicznych. Wynika to z faktu, że już na etapie tworzenia sylabusa należy wziąć pod uwagę, że „nasze postrzeganie świata jest podłączone do kulturowych wyobrażeń - uwarunkowane przez narracje, stereotypy i uprzedzenia. Geografia jest pochodną postrzegania, a nie twardych danych” (Czapliński, 2016, s. 9). W powyższym cytacie jego autor - Przemysław Czapliński - nawiązuje, oczywiście, do wprowadzonego przez Edwarda Saida określenia: geografia wyobrażona. Pedagogiczna świadomość zaprezentowanego tu sposobu oglądu świata - z perspektywy kulturowych wyobrażeń - determinuje proces dydaktyczny. Wymaga bowiem przedstawienia narzędzi umożliwiających „wyjście” z narracji jednostronnych i stereotypowych wizji społecznych. Jednym z istotnych takich narzędzi jest język opisu pograniczy, który w edukacji akademickiej - w moim przekonaniu - nie może mieć innego charakteru niż policentryczny. 
Oznacza to, że język ten już w warstwie pojęciowej ma uwzględniać wielostronne i różnowymiarowe punkty odniesienia typowe dla badawczej analizy z pozycji zewnętrznej obserwacji (Lewicka, 2012, s. 12; Taborska, 2017/2019, s. 14-15) i zgodnej z myślą Georga Hansa Gadamera, który jako hermeneuta postrzegał źródła wiedzy o człowieku w wielości oraz różnorodności interpretacji tekstów kultury (Gadamer, 2004).

Celem niniejszego szkicu jest kolejna propozycja autorska (Taborska, 2017/2019) wprowadzenia policentrycznych pojęć i klasyfikacji ułatwiających analizy zjawisk kulturowych występujących na pograniczach niemiecko-polskich. Użyte tu zgodnie z porządkiem alfabetycznym sformułowanie „niemiecko-polskie pogranicza” sygnalizuje konieczność tworzenia intersubiektywnie zgodnych reguł opisu miejsc różnych kultur.

\section{1. „ZIEMIA WIELOKROTNA” I INNE POJĘCIA}

Tytułowe pojęcie tego artykułu: „ziemia wielokrotna” skonstruowano, wykorzystując występujące w prozie autobiograficznej Edwarda Balcerzana określenie: „ojczyzna wielokrotna” (Balcerzan, 2003, s. 25). Geopoetyczny termin autora zbioru Perehenia i słoneczniki rozumieć można jako językowe odzwierciedlenie przestrzeni bliskiej człowiekowi wielojęzycznemu, który czuje związek z różnymi obszarami kulturowymi i geograficznymi, a jednocześnie nie ma potrzeby ich hierarchizowania czy strukturalizowania.

Sergiusz Sterna-Wachowiak, komentując myśl Balcerzana i - jak to nazwał: „antyutopijne pojęcie »ojczyzny wielokrotnej«” (Sterna-Wachowiak/Balcerzan, 2003, s. 18) - zaproponował następujące obrazowe dookreślenie tego terminu:

Wielokrotność, łaska wielokrotności jest tajemnicą i cudem, jak dar siedmiu żywotów każdego kota albo jak zmultiplikowany biogram aktora, wcielającego się podczas teatralnych wieczorów swojego życia w liczne charaktery, osobowości i kostiumy. Mieszkaniec „ojczyzny wielokrotnej” to nie wygnaniec z „ojczyzny dużej” ani obcy w „małej ojczyźnie”, lecz prędzej bywalec wielu takich i innych jeszcze ojczyzn (Sterna-Wachowiak/Balcerzan, 2003, s. 19).

Termin „ojczyzna wielokrotna” wiąże się z koniecznością odniesienia go w pierwszym rzędzie do konkretnego człowieka i jego pojmowania świata; określenie „ziemia wielokrotna” wiąże się z obrazowaniem konkretnego miejsca. Jak definiować zatem występujący w tytule tego artykułu termin? Jest to określenie 
bliskie wyrazowi: pogranicza. Ma jednak szerszą treść. Zawiera się w nim bowiem bogactwo wielu kultur i języków charakterystycznych dla miejsc styków niejednorodności².

Określenia „ziemia wielokrotna” można używać do charakteryzowania różnych pograniczy. Z pewnością termin ten jest adekwatną nazwą dla kolejnego wyrażenia z tytułu niniejszego szkicu: nowych pograniczy niemiecko-polskich. To przestrzenie wielokulturowe, które zaczęły się kształtować w wyniku przesunięć granic Polski na zachód po drugiej wojnie światowej. Cechują je różnorodne znaki styków kulturowych, w tym: polsko-polskie (powstałe w wyniku osiedlenia się tam przybyszów z wielu krain polskich) i polsko-niemieckie, a także inne, w tym: polsko-romskie, ukraińskie czy żydowskie. Mozaiki wielokrotności można odnajdować w różnych miejscach nowych pograniczy.

Termin „ziemia wielokrotna” ma charakter policentryczny - jego użycie determinuje wieloperspektywiczny ogląd ziem inkorporowanych przez Polskę w 1945 roku oraz zjawisk na nich zachodzących. Innymi słowy: użycie terminu uruchamia konieczność uwzględnienia różnych wpływów kulturowych i poszukiwania zjawisk oraz procesów występujących w ich obrębie.

Badawcze opisywanie nowych pograniczy wymaga szczególnej wrażliwości metajęzykowej, która - w moim przekonaniu - powinna łączyć się z odejściem od nazewnictwa funkcjonującego w obrębie mitów: polskiego „ziem odzyskanych” oraz niemieckiego: „utraconego Heimatu”. Określenie „ziemia wielokrotna” wydaje się w tym pomocne. Ma bowiem charakter neutralny. Nie determinuje - jak określenie „pogranicze” - doprecyzowań, które nierzadko stają się miejscem wykluczenia niewymienionych Innych. Jeśli dziś powiemy: pogranicze niemiecko-polskie, to w zależności od konkretnego miejsca, które mamy na uwadze, nie będzie w tym określeniu choćby w przypadku Górnego Śląska samych Ślązaków, a w przypadku Pomorza Zachodniego np. Łemków czy Tatarów.

Jak się zdaje, użycie terminu „ziemia wielokrotna” może ułatwić również porozumienie w sferze przekładów oraz uwrażliwić na konieczność oglądu fenomenów pograniczy z wielu perspektyw. Ten rodzaj uwrażliwienia uwidacznia się już w niektórych współczesnych monografiach naukowych, czego dowodem jest praca

2 Pojęcie „ziemia wielokrotna” definiowano już w artykule Strategie kreowania wizerunków dziecka w narracjach autobiograficznych pokolenia wojenno-pojałtańskiego, „Autobiografia. Literatura. Kultura. Media” 2019, nr 1. W tej wypowiedzi wykorzystano również terminologię, analizy i ustalenia, które przedstawiono w monografii Literatura miejsca. Piśmiennictwo postlandsberskie, Gorzów Wielkopolski 2017/2019. Dotyczy to między innymi alfabetycznego układu epitetu „niemiecko-polski” w miejsce występującego w uzusie polszczyzny określenia: „polsko-niemiecki”. 
Anny Zielińskiej Mowa pogranicza. Studium o językach i tożsamościach w regionie lubuskim (Zielińska, 2013) ${ }^{3}$. Swoje badania autorka przedstawia następująco:

Od roku 2009 do roku 2013 prowadziłam badania terenowe, polegające na przeprowadzaniu pogłębionych wywiadów z najstarszymi mieszkańcami regionu, którzy pod koniec II wojny światowej lub niedługo po niej zaznali wielkiej zmiany - zerwania więzi z miejscem urodzenia oraz więzi sąsiedzkich i nierzadko rodzinnych.

Mieszkańcy regionu lubuskiego po 1945 roku zostali poddani eksperymentowi socjotechnicznemu, którego celem miała być zmiana ich tożsamości. Zgodnie z mitem „ziem odzyskanych” mieli przestać być Niemcami, Polakami z kresów wschodnich, Poleszukami, Bukowińczykami, Ukraińcami, Łemkami, Cyganami, ludźmi o różnych lokalnych tożsamościach, o podwójnych tożsamościach (np. polsko-niemieckiej), mieli się stać Polakami, członkami „nowego społeczeństwa ziem odzyskanych”, świadczącymi zuniformizowaną kulturą narodową i zunifikowanym „najczystszym” językiem polskim o polskości przyłączonych do państwa polskiego w 1945 roku ziem niemieckich. Na ile ten eksperyment się udał?

Prowadząc badania w różnych miejscach województwa lubuskiego, zorientowałam się, że różnorodność kultur, języków i identyfikacji wciąż tutaj istnieje. Region jest zamieszkany w dużym stopniu przez dwujęzyczne osoby i grupy. Zachodzą tu typowe dla bilingwizmu procesy społeczne i językowe. Aktywne jest wciąż mówienie nie tylko różnymi językami, ale także gwarami (Zielińska 2013, s. 10-11).

Badaczka nie tylko udowodniła wielokulturowość i wielojęzyczność nowego pogranicza, ale również stworzyła unikatowy zbiór narracji ludzi, którzy wbrew naciskom społeczno-politycznym nie ulegli propagandowej homogenizacji i nie zatracili swoich języków i tożsamości. Studium Anny Zielińskiej ukazuje też absurdalność stwierdzenia: „najczystsza polszczyzna”. Ten wyimaginowany język miał być charakterystyczny dla mieszkańców nowych pograniczy, a jest on jedynie tworem wyobrażonym - jednym z wielu mitów nowych pograniczy.

${ }^{3}$ Niemiecka wersja tego studium ukazała się pod następującym adresem bibliograficznym: Grenzlandsprache. Untersuchung der Sprachen und Identitäten in der Region Lebus, przeł. Klaus Steinke, Peter Lang Verlag, Berlin 2019. 


\section{SPOSOBY OBRAZOWANIA ZIEMI WIELOKROTNEJ W WYBRANYCH TEKSTACH KULTURY}

Anna Zielińska w swojej pracy wykorzystała antropologiczną metodę wywiadu pogłębionego. Udało jej się w ten sposób zgromadzić liczne narracje mieszkańców ziemi wielokrotnej. Każda przedstawiona przez badaczkę w zapisie fonetycznym mowa pogranicza jest indywidualnym świadectwem życia na ziemi wielokrotnej; narracją powstałą w wyniku wielogodzinnych spotkań i rozmów. Wydając monografię, Anna Zielińska stała się twórczynią antologii narracji pograniczy. Formalnością zdaje się stwierdzenie, że ten sposób prezentowania ziemi wielokrotnej należy do badawczo-ekscerpujących, gdyż narracje przedstawione w omawianym studium są podporządkowanymi celom naukowym wycinkami - tekstami wyekscerpowanymi - z wielogodzinnych wywiadów.

Badając teksty kultury pograniczy przeznaczone przez ich twórczynie i twórców dla szerszej publiczności, zaobserwować można różne sposoby obrazowania ziemi wielokrotnej. W niniejszym artykule na wybranych przykładach przedstawiono trzy z nich:

a) eliminacyjno-jednostronny /-jednowartościujący4;

b) odkrywczo-dokumentacyjny;

c) prezentacyjno-archiwizujący.

Wymienione powyżej określenia wskazują na podejście do obrazowania ziemi wielokrotnej. Pierwszy człon nazywa istotę czynności autorskiej: eliminowanie, odkrywanie, prezentowanie; drugi element z określenia ukazuje formę przedstawiania obrazu pogranicza: tekst jednowartościowy, tekst dokumentalny, tekst historyczny (archiwalny).

\section{a) Obraz eliminacyjno-jednowartościujący}

Tworzenie jednostronnego konterfektu miejsc przejętych przez Polskę w 1945 roku łączące się z programową eliminacją Innych i ich historii oraz dorobku kulturowego można przedstawić na przykładzie wierszy polskich powstałych w drugiej połowie lat czterdziestych XX wieku. Stanowią one swego rodzaju wzór polskocentrycznego oglądu nowych pograniczy, który powtarzany był w różnogatunkowych tekstach w kolejnych dziesięcioleciach ${ }^{5}$. Jak się zdaje, jest to też

${ }^{4}$ Odwołuję się tu, rzecz jasna, do opracowania Michała Głowińskiego Nowomowa po polsku (Warszawa 1990), w którym ukazano język propagandy peerelowskiej. W ramach tego języka funkcjonował mit ,ziem odzyskanych”.

${ }^{5}$ Odpowiedniki niemieckocentrycznego, jednostronno-eliminacyjnego oglądu nowych pograniczy znaleźć można w różnorodnych tekstach byłych mieszkańców tych ziem, zob. np. Die 
jedno ze źródeł generujących mit najczystszej polszczyzny nowych pograniczy niemiecko-polskich. Ten sposób kreowania konterfektów nowych pograniczy wiąże się z tworzeniem jedynej istotnej, czyli polskiej, historii tych ziem i dotyczył także miejsc, których z historią Polski do 1945 roku nic lub prawie nic nie łączyło.

Zgodnie z instrukcją pozostawioną przez Zygmunta Wojciechowskiego należało upowszechnić polski wizerunek inkorporowanych obszarów. We wstępie do części pierwszej monografii nowych pograniczy twórca Instytutu Zachodniego stwierdził otwarcie: „Zadanie nasze polegało na przedstawieniu polskiej historii tych ziem i rzuceniu polskiej współczesnej rzeczywistości tych ziem na owo tło historyczne. Takie postanowienie sprawy dyktowały nie tylko potrzeby chwili obecnej, ale również przekonanie, że polska historia tych ziem jest ich historią najgłówniejszą”ø (Wojciechowski, 1948, s. 10-11).

Stwierdzenie o „historii najgłówniejszej” pochodzi z 1948 roku, ale teksty pisane w myśl tej tezy pojawiły się już wcześniej. Cechuje je ucieczka od inności, niezauważanie historii i znaków kulturowych stworzonych przez Innych lub obsadzanie Innego w roli w wiecznego wroga. Takie obrazy nowych pograniczy są typowe między innymi dla tekstów powstałych w kręgu mitu „ziem odzyskanych”.

Tużpowojenną egzemplifikacją programowego spolszczania konterfektu ziemi wielokrotnej oraz ukrywania i zamazywania niepolskiej historii miejsc nowych pograniczy są wiersze z tomiku Leszka Golińskiego i Franciszka Fenikowskiego, który ukazał się w 1946 roku pod znamiennym, eliminującym niemieckość tytułem Odra szumi po polsku. Zbiór opublikowano w Wydawnictwie Zachodnim w Poznaniu (Goliński, Fenikowski, 1946). Jest to chyba pierwszy tematyczny zbiór tekstów wierszowanych, które opisują terytoria włączone do Polski na mocy układów jałtańsko-poczdamskich. Już same tytuły utworów pokazują przestrzeń opisywaną przez Leszka Golińskiego (oto wybrane z nich: Ślq̨sko Opolskie, Odra, Wrocław, Odjazd z Wrocławia, Szczecin, Most nad Nisq - taka nazwa rzeki funkcjonowała tuż po wojnie) oraz Franciszka Fenikowskiego (przykłady tytułów wierszy tego autora: Odra szumi po polsku, Nad Odrq świta, Wiosna zachodnia, Wieczór w Gorzowie, Ziemia Lubuska, Jesień zielonogórska, Górny Ślq̨sk, Z Karkonoszy, Na gruzach Gdańska). Nietrudno zauważyć, że ambicją autorów było stworzenie możliwie szerokiej wierszowanej panoramy nowych terytoriów Polski.

Vertreibung der deutschen Bevölkerung aus den Gebieten östlich der Oder-Neiße, Herausgegeben von ehemaligen Bundesministerium für Vertriebene, Flüchtlinge und Kriegsgeschädigte, München 1995 (I/1), 1993 (I/2), 1993 (I/3).

6 Z. Wojciechowski, Słowa wstępne, w: Dolny Ślq̨sk, cz. 1 (seria „Ziemie Staropolskie”), red. Kirył Sosnowski, Mieczysław Suchocki, Instytut Zachodni, Poznań 1948, s. 10-11. 
Jednym z ciekawszych wierszy zbioru, oddającym istotę eliminacji niemieckiej historii miejsca, jest utwór Fenikowskiego Wieczór w Gorzowie. Tekst powstał dzięki wykorzystaniu fantazmatu piastowskiego miasta i połączeniu go z polską tradycją literacką. Warto nadmienić, że dzisiejszy Gorzów Wielkopolski był do 1945 roku niemieckim Landsbergiem, głównym ośrodkiem kulturowym Nowej Marchii. Nikłe związki z Polską nie wpływały przez wieki na rozwój tego miasta. Dodany w 1945 roku do polskiej nazwy miasta epitet „Wielkopolski” nie miał żadnego historycznego uzasadnienia. Utwór Fenikowskiego opisujący ten nadwarciański gród zaczyna się od nawiązania do fraszki Kochanowskiego i innych sielanek polskich:

Lipy tutaj Czarnolasem pachną

I tęsknotą w lśniącej wodzie toną...

Dzień się żegna z Ziemią zapłonioną,

Jak w znajomej piosnce Jaś z Kachną.

W ostatniej, czwartej strofie pojawia się wyznanie podmiotu mówiącego:

Jak mi dobrze! Lipy brzmią jak skrzypce,

[...]

Ziemia zbladła chyli ku mym ustom

Dzban z piastowskim, szczerozłotym lipcem (Goliński, Fenikowski, s. 43)

Sielankowość scenerii wiersza jest nieadekwatna do powojennej rzeczywistości opisywanego miejsca, wpisuje się w ogólną tendencję polskocentrycznego obrazowania miejsca nowych pograniczy.

Dowodem możne być napisany w tej samej konwencji wiersz Konstantego Ildefonsa Gałczyńskiego, który w okresie tużpowojennym miał tworzyć środowisko literackie w Szczecinie. Prezentowany poniżej utwór został opublikowany 2 października 1948 roku w tysięcznym numerze „Kuriera Szczecińskiego”. Gałczyński chciał w ten sposób uczcić jubileusz periodyku. Poniżej kopia fragmentu z wymienionego czasopisma:

\section{SZCZECIN}

Tutaj mój port, tu słońce mam na czole i dom i sad i kota - nie do wiary!

7 Zapomniany wiersz Gałczyńskiego?, http://sedina.pl/wordpress [dostęp: 15.08.2020]; skan to fragment „Kuriera Szczecińskiego” z 2 X 1948. 
Natalia na werandzie Kira w szkole.

A babci wchodzą sny pod okulary

Nad klombem ptaka cień przefrunął modry.

Grzmi w rękopisie moim epopeja.

Dobrze mi tu. I wieje wiatr od Odry, odurzający i zwycięski jak nadzieja ${ }^{8}$.

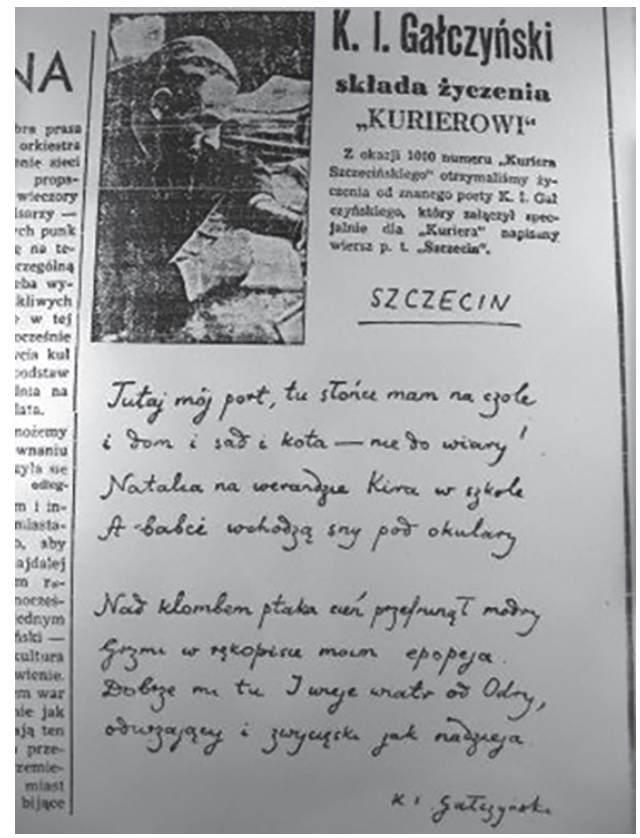

Jak już stwierdzono, wiersz Gałczyńskiego wpisuje się w schemat ówczesnych społeczno-politycznych wymogów tworzenia tekstów kultury ukazujących miejsca włączone do Polski w 1945 roku. W pierwszej zwrotce ukazana została intymistyczna wizja spokojnego życia rodzinnego poety w Szczecinie. Wzmocniona w części drugiej przez stwierdzenie: „Dobrze mi tu”. W tej zwrotce pojawia się również wątek autotematyczny. Pojedynczy wers z tej strofy przedstawia tworzenie nowego, wielkiego dzieła pisarza („Grzmi w rękopisie moim epopeja”). Idyllę życia szczecińskiego uzupełnia metaforyczne przesłanie kryjące się w opisie zwycięskiego wiatru od Odry. Ten ostatni motyw koresponduje z treścią tomiku

\footnotetext{
8 Tamże.
} 
Odra szumi po polsku. Dla porównania można przytoczyć fragment ostatniego wiersza z poznańskiego zbioru:

$[\ldots]$

Ziemia wyprężona, jak młoda dziewczyna,

W tchnieniu wichru, co ją zbudził skamieniałą,

Odrę, jak łuk srebrny, zwycięsko napina

I celuje w słońce nowego dnia strzałą.

[...] (Goliński, Fenikowski, s. 54)

Na zakończenie tej części warto przytoczyć wiersz opublikowany w periodyku „Ziemia Gorzowska” wydanym z datą 16 września 1945 roku. Jest to utwór, który pokazuje, jak trudno było zbudować wzór geopoetyckiej wizji nowych pograniczy oraz ile - wbrew pozorom - inwencji i wysiłku kreacyjnego wymagała przedstawiona w cytowanych wcześniej utworach sielankowa wizja ziem przyłączonych do Polski po drugiej wojnie światowej. Niżej zamieszczono pierwszą publikację tekstu Serce i pancerz, aby wyeksponować zarówno oryginalną interpunkcję stylizowaną na zapis norwidowski, jak i specyfikę ówczesnego drukarstwa.

Ten wiersz jest również interesujący z co najmniej kilku innych jeszcze powodów:

"Ziemia Gorzowska”

$1945 \mathrm{nr} 11, \mathrm{~s} .2$.

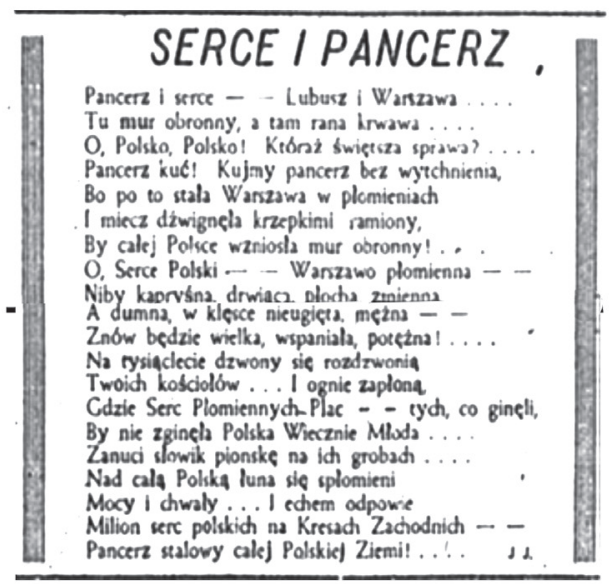


- pokazuje nierealistyczny obraz powojennych, nowych granic Polski Lubusz (niem. Lebus) - średniowieczna stolica historycznej ziemi lubuskiej - leży po zachodniej stronie Odry, czyli wówczas w radzieckiej strefie okupacyjnej Niemiec;

- widoczne w nim czynienie z Lubusza - pancerza - symbolicznej stolicy nowego pogranicza może wyrażać wolę większego rozszerzenia granic Polski na zachód; ta interpretacja wiąże myśl zawartą w utworze z koncepcjami terytorialnymi przedstawianymi przez Polski Związek Zachodni9;

- wiersz unaocznia chaos wyobrażeniowy związany z nadaniem w 1945 roku nowemu regionowi Polski nazwy „ziemia lubuska” ta nowa nazwa geograficzna i jej nieadekwatność historyczna stanowią istotny element mitu „ziem odzyskanych”;

- jedenastozgłoskowiec ujawnia społeczną potrzebę kreowania symboliki miejsc: serce - Warszawa; pancerz - Lubusz, a z nim całe nowe zachodnie pogranicze Polski;

- utwór jest też lirycznym świadectwem nierozerwalności oraz trwałości powojennego kształtu Polski; jest to, co oczywiste, świadectwo paradoksu z uwagi na jedno z miast - bohaterów wiersza - należący do Niemiec: Lebusz (Lebus), które uczyniono symbolem „Polski Wiecznie Młodej”.

Gałczyński, Fenikowski i Goliński oraz wielu innych współtworzyli poetycką mapę (geografię wyobrażoną) nowych terytoriów Polski, która silnie oddziaływała na język obrazowania i sposób odbioru nowych pograniczy. Teksty wykluczające obcych i tworzące polskocentryczną historię miejsc ziemi wielokrotnej są doskonałym przykładem kształtowania jednowartościowych wzorców rozumienia przeobrażeń geopolitycznych powtarzających się do dziś w różnych tekstach kultury.

b) Obraz odkrywczo-dokumentacyjny

Charakterystyczne dla przemian po 1989 roku jest odrzucenie jednowartościowego wzorca ukazywania nowych pograniczy, poszukiwanie przeszłości ziemi wielokrotnej oraz docenienie tradycji kulturowej jej dawnych i współczesnych mieszkańców. Powstały już ważne diagnozy dotyczące literatury związanej z odkrywaniem ziemi wielokrotnej, które zawierają propozycje terminologiczne pre-

${ }^{9}$ Członkowie Polskiego Związku Zachodniego wysuwali postulaty utworzenia nowej granicy Polski na co najmniej trzydzieści kilometrów po lewej stronie Odry; zob. artykuł Michała Musielaka, Polski Zwiq̨zek Zachodni a granica na Odrze i Nysie Łużyckiej w latach 1945-1948, „Przegląd Zachodni” 1985, nr 1. W tym kontekście łatwiej zrozumieć ideę utworzenia nowego regionu Polski o nazwie ziemia lubuska. 
cyzujące skomplikowany układ nadawczo-odbiorczy zjawisk występujących na nowych pograniczach ${ }^{10}$.

W tym szkicu za przykład artystycznego odkrywczo-dokumentacyjnego obrazu ziemi wielokrotnej wybrano film dokumentalny twórców gorzowskich: Moniki Kowalskiej, Grzegorza Kowalskiego i Zbigniewa Sejwy, dla których istotne stało się poznanie przeszłości ich miasta. Film - Wspomnienia z miasta L. / Errinerungen aus der Stadt L. - który powstał w 2004 roku, odkrywa niemiecką przeszłość miejsca oraz utrwala w zapisie filmowym narracje dawnych mieszkańców dzisiejszych zachodnich miejscowości polskich. Twórcy dzieła zauważyli i jednocześnie odrzucili mityczny, polonocentryczny obraz nowego pogranicza. Widać to wyraźnie w następującej wypowiedzi: „Chcieliśmy się dowiedzieć, jakim miastem był Gorzów przed wojną. Interesowała nas kwestia pamięci, ale nieoficjalnej. Bo właściwie nikt przeszłości miasta nie znał, jego historia zaczynała się w 1945 roku wraz z mitycznym wyzwoleniem" ${ }^{11}$. W tym krótkim cytacie ujawnia się nie tylko nieznajomość historii miejsca wynikająca z braku kontaktu z ludźmi żyjącymi w mieście przed 1945 rokiem, ale także schemat konstrukcyjny mitu „ziem odzyskanych”, który kreował wyobrażenia o miejscu, wymazując niemieckość i jej rolę w historii. Użycie słowa „wyzwolenie” zamiast „zdobycie przez Armię Czerwoną niemieckiego wówczas miasta” wiąże się z tworzeniem historii alternatywnej czy (lub czyli) mitu. Miały one ułatwić przybyszom osiedlenie się na terenach, które do 1945 roku należały do Niemiec.

Autorom filmu udało się „,wejść” w świat niemieckich mieszkańców miasta, a zarazem „wyjść” z mitu „odzyskania”. Dokument w całości zrobiony przez Polaków pokazuje Niemców, dla których Gorzów pozostanie na zawsze miastem dzieciństwa - rodzinnym nowomarchijskim Landsbergiem. „Jego fabułą stały się wspomnienia dawnych mieszkańców, którzy opowiadają o swoim dzieciństwie spędzonym w przedwojennym Gorzowie w latach 1935-1945 i których przesiedlono do Niemiec. Bohaterami są Brigitte Brandenburg (córka przedwojennego właściciela tartaku), Christa Greuling (córka piekarza Karla Lucka), Gisela Opitz (córka pastora), Christine Reinecke, Hans Jurgen Reso (syn pastora) i Herbert Schimmel. Ich opowieści przeplatane są starymi fotografiami Landsbergu, na których utrwalono miejsca przywoływane we wspomnieniach”12.

10 Zob. np. Narracje migracyjne w literaturze polskiej XX i XXI wieku, red. H. Gosk, Universitas, Kraków 2012; w tym zbiorze opublikowany został między innymi artykuł Ingi Iwasiów Hipoteza literatury neo-post-osiedleńczej.

11 Z. Sejwa, M. Kowalska, G. Kowalski, https://encyklopedia.wimbp.gorzow.pl/w/wspomnienia_l_film/wspomnienia_l_film.html [dostęp: 10.08.2020].

12 Tekst ze strony: https://mckgorzow.pl/spotkania-ze-sztuka-wspomnienia-z-miasta-l/ [dostęp: 
Landsberczycy ukazują gorzowianom nieznane w Polsce obrazy z historii ich wspólnego miasta. Zatem przekazicielami historii są jednocześnie i Inni, i Swoi - gorzowianie - twórcy nietuzinkowej formy medialnej. W ten sposób film staje się dowodem na ciągłość historii miejsca, na jego wielokrotność oraz związany z nią palimpsestowy charakter miasta. Ten fenomen przekazu decyduje o wartości artystycznej i eksploracyjnej obrazu. Warto dodać, że film „uwodzi” swoim artyzmem, jego prostota zaskakuje, a jednocześnie jest kluczem do uznania tego dokumentu za dzieło sztuki.

O tym, jak trudne jest zaakceptowanie przedstawionej w filmie perspektywy oglądu ziemi wielokrotnej, świadczy sam tytuł spotkania, które odbyło się w grudniu 2018 roku w ramach działań Inkluzywnej Pracowni Edukacji Artystycznej Miejskiego Centrum Kultury w Gorzowie Wielkopolskim: Wspomnienia z miasta L. Polifonia pamięci czy pamięć nie do pogodzenia? Rozmowy o filmie, prowadzone kilkanaście lat po jego powstaniu, pokazują również aktualność problemu sposobów kreowania wyobrażeń o nowych pograniczach.

\section{c) Odbiór prezentacyjno-archiwizujący}

Film Kowalskich i Sejwy odkrywa zindywidualizowane wizje niemieckości miejsc nowego pogranicza. Innego zadania podjęła się Hannelore Scholz-Lübbering. We współpracy z Hildegard Lämmer wydała dwa zbiory „rozmaitych historii”, które dowodzą bogactwa różnorodności narracji miejsc ziemi wielokrotnej. Są one świadectwem tradycji obszarów leżących dziś na pograniczach Niemiec i Polski: tradycji prymarnie oralnej, wtórnie piśmiennej.

Pierwszy z tomów ukazał się w języku niemieckim jako: Allerei Geschichten aus der Oderbruch, (Scholz-Lübbering, Lämmer (red.), 2009). Drugi jest dwujęzyczny, o czym świadczy już sam rozbudowany tytuł antologii: Wie die Oder rauscht. Allerlei Geschichten entlang der Oder und aus der Neumark / Jak szumi Odra. Rozmaite historie znad Odry i z Nowej Marchii (Scholz-Lübbering, H. Lämmer (red.), 2012). Ten tytuł, wbrew pozorom, nie nawiązuje do omawianego wyżej tomiku polskich wierszy z 1946 roku ${ }^{13}$. Jednak dwa odmienne wyobrażenia szumu Odry w tytułach ujawniają odrębne perspektywy oglądu rzeczywistości tych, którzy komponowali omawiane tu tomy.

Trzeci zbiór badaczka z Berlina opublikowała wraz z Renatą Dampc-Jarosz w języku polskim pod tytułem: Nadodrzańskie opowieści. Antologia tekstów

20.08.2020]; zob. też https://encyklopedia.wimbp.gorzow.pl/w/wspomnienia_l_film/wspomnienia_l_film.html [dostęp: 10.08.2020].

13 Tę informację uzyskano od redaktorki zbioru - Hannelore Scholz-Lübbering. 
niemieckich autorów z obszaru Środkowej i Dolnej Odry przed 1945 rokiem (Dampc-Jarosz, Scholz-Lübbering (red.), 2019). We wstępie do polskojęzycznego zbioru jego autorki, powołując się na myśl Kazimierza Brakonieckiego, Jürgena Joachimsthalera i Roberta Traby (Dampc-Jarosz, Scholz-Lübbering/red., 2019, s. 7), wpisują się do grona prezentujących narracje ziemi wielokrotnej. Podkreślają, że celem wydawania różnogatunkowych tekstów związanych z miejscami nowych pograniczy niemiecko-polskich jest ich „ponowne (...) wprowadzenie do świadomości mieszkańców po obu stronach Odry” (Dampc-Jarosz, Scholz-Lübberin (red.), 2019, s. 8).

Wśród wymienionych zbiorów szczególną uwagę zwraca dwujęzyczna antologia „historii rozmaitych”. Zawiera ona baśnie, podania, legendy, sagi, jak również inne narracje związane z rzeką Odrą i jej okolicami oraz Nową Marchią. (Znalazły się w niej nawet fragmenty wspomnień Victora Klemperera, który urodził się w Landsbergu). Antologia została skonstruowana jako przewodnik po miejscowościach leżących na wymienionych obszarach. Redaktorki utworzyły cztery trasy wędrówek dla zainteresowanych zwiedzaniem miejsc i poznawaniem ich tradycji narracyjnej. Rozmaite historie, obok opowieści, zawierają również charakterystyki miejscowości, z którymi związana jest przedstawiana w zbiorze opowieść ${ }^{14}$. Zbiór jest zatem jednocześnie przestrzenią prezentacji i archiwizacji rozproszonych dotychczas narracji miejsc, jak i oryginalnym bedekerem po ziemi wielokrotnej.

Dwujęzyczny przewodnik wykorzystać można jako materiał dydaktyczny na różnych poziomach nauczania. Opierając się na tekstach z tej antologii zorganizowano w Moryniu we wrześniu 2016 roku grantowe warsztaty dla studentów germanistyki i polonistyki Akademii im. Jakuba z Paradyża ${ }^{15}$. Z Moryniem (niem. Mohryn) związane są różnorodne podania i legendy, które kreują wyobrażenia o miejscu. W ramach projektu Baśniowy Moryń uczestnicy rozwijali kompetencje literaturoznawcze, translatorskie czy metodyczne, jak również odkrywali historię miejsca z perspektywy kultury narracyjnej danego terytorium. Warto nadmienić, że w ewaluacyjnej prezentacji efektów pracy warsztatowej wzięli udział mieszkańcy Morynia.

14 Niektóre fragmenty w tej części można by uzupełnić, na przykład dodać polski odpowiednik do niemieckiej miejscowości Lebus i zwrócić uwagę na genezę nazwy dzisiejszego województwa lubuskiego oraz ziemi lubuskiej.

15 Warsztaty prowadziły badaczki związane z Pracownią Badań nad Literaturą i Czasopiśmiennictwem Pogranicza Akademickiego Centrum Badań Euroregionalnych AJP w Gorzowie Wielkopolskim: Hannelore Scholz-Lübbering (kierowniczka projektu), Małgorzata Czabańska-Rosada, Małgorzata Lipińska, Katarzyna Taborska. 
Antologie wydawane z inspiracji Hannelore Scholz-Lübbering zostały obudowane metodologicznie poprzez wprowadzenia zawierające wskazówki dotyczące odbioru zawartych w tomach narracji. Zbiory prezentujące „rozmaite historie” miejsc są ważnym punktem odniesienia dla poszukujących śladów tożsamościowych ziemi wielokrotnej i chyba również trudno przecenić ich wartość jako rezerwuaru tradycji.

Ogląd tekstów kultury przez pryzmat sposobów ukazywania w nich konterfektów ziemi wielokrotnej otwiera nowe pola interpretacyjne, wymaga przygotowania się na wielokrotność, czyli na poszukiwanie i rozumienie Innego. To istotne zadanie edukacyjne. Takiej właśnie recepcji mają służyć propozycje terminologiczne sklasyfikowane w tym szkicu.

Bibliografia (wybór w układzie chronologicznym)

Goliński, L., Fenikowski, F. (1946). Odra szumi po polsku. Poznań: Wydawnictwo Zachodnie.

Wojciechowski, Z. (1948). Słowa wstępne. W: K. Sosnowski, M. Suchocki (red.). Dolny Ślqzsk, cz. 1 (seria „Ziemie Staropolskie”). Poznań: Instytut Zachodni.

Musielak, M. (1985). Polski Związek Zachodni a granica na Odrze i Nysie Łużyckiej w latach 1945-1948. Przegląd Zachodni, 1.

Głowiński, M. (1990). Nowomowa po polsku. Warszawa: PEN.

Balcerzan, E. (2003). Perehenia i słoneczniki. Wstęp S. Sterna-Wachowiak. Poznań: Stowarzyszenie Pisarzy Polskich.

Gadamer, H.-G. (2004). Prawda i metoda. Zarys hermeneutyki filozoficznej. Tłum. B. Baran. Warszawa: PWN.

Scholz-Lübbering, H., Lämmer, H. (red.). (2009). Allerei Geschichten aus der Oderbruch. Vevais: Galerie.

Kowalczyk, I. (2011). Podróż do przeszłości. Interpretacje w polskiej sztuce krytycznej. Warszawa: Wydawnictwo SWPS Academica.

Scholz-Lübbering, H., Norden, B. (red). (2011). Götter, Geister, Wassernixen entlang der Oder. Ergebnisse einer Tagung in Słubice im September. Leipzig: Leipziger Universitätverlag.

Gosk, H. (red). (2012). Narracje migracyjne w literaturze polskiej XX i XXI wieku. Kraków: Universitas.

Scholz-Lübbering, H. Lämmer, H. (red.). (2012). Wie die Oder rauscht. Allerlei Geschichten entlang der Oder und aus der Neumark / Jak szumi Odra. Rozmaite historie znad Odry i z Nowej Marchii. Tłum. R. Dampc-Jarosz. Leipzig: Leipziger Universitätverlag. Zielińska, A. (2013). Mowa pogranicza. Studium o językach i tożsamościach w regionie lubuskim. Warszawa: Slawistyczny Ośrodek Wydawniczy.

Taborska, K. (2017/2019). Literatura miejsca. Piśmiennictwo postlandsberskie. Gorzów Wielkopolski: Wydawnictwo Naukowe AJP. 
Dampc-Jarosz, R., Scholz-Lübbering, H. (red.) (2019). Nadodrzańskie opowieści. Antologia tekstów niemieckich autorów z obszaru Środkowej i Dolnej Odry przed 1945 rokiem. Katowice: Śląsk.

Taborska, K. (2019). Strategie kreowania wizerunków dziecka w narracjach autobiograficznych pokolenia wojenno-pojałtańskiego. Autobiografia. Literatura. Kultura. Media, 1. Zielińska, A. (2019). Grenzlandsprache. Untersuchung der Sprachen und Identitäten in der Region Lebus, Tłum. K. Steinke. Berlin: Peter Lang Verlag. 